\title{
Chapter 15 \\ The Economic Impact of the Universities in the State of Baden-Württemberg
}

\author{
Johannes Glückler, Robert Panitz, and Christian Wuttke
}

A geographical understanding of the role of universities in society includes an appraisal of the impact they have on their regional economies. Over the past twenty years, academic and public interest in the economic effects of higher education institutions has risen dramatically. Two reasons for this change are the increasing globalization of and the mounting economic competition for knowledge and innovation. Because economic development depends ever more on creativity and innovation, academia and the public have sought to improve the understanding of the role that universities play in economic growth. This search is manifested in conceptual approaches such as national and regional innovation systems (Cooke, Heidenreich, \& Braczyk, 2004; Lundvall, 1992), varieties of capitalism (Hall \& Soskice, 2001), and the triple-helix model (Etzkowitz, 2008; see chapter by Etzkowitz in this volume). Further reasons for the elevated interest in the impact of universities are recent retrenchment policies in the aftermath of the financial and economic crises in North America and Europe since 2008. Budget constraints have intensified the competition for public funding, calling for more detailed assessments of the benefits of higher education as compared to alternative uses of funding (e.g., Hamm \& Wenke, 2002). The competition is not only for direct funding but also for land use in urban planning, with universities pressing the argument that their positive economic impact on the city trumps alternative uses.

It is utterly impossible to quantify all the diverse economic impacts that universities have on the economy, especially over long periods and from geographical perspectives. A research activity, for example, may promote the production of new knowledge as well as the qualification of students and, many years later, may generate spin-offs or royalties from patent-related contracts. The sheer breadth of the university's activities and contributions to society and the economy is

\footnotetext{
J. Glückler $(\bowtie) \cdot$ R. Panitz $\cdot$ C. Wuttke

Department of Geography, Heidelberg University, Heidelberg, Germany

e-mail: glueckler@uni-heidelberg.de; panitz@uni-heidelberg.de; wuttke@uni-heidelberg.de
} 
extraordinary (Bathelt \& Schamp, 2002; Drucker \& Goldstein, 2007; Goldstein, Maier, \& Luger, 1995; Goldstein \& Renault, 2004; Salter \& Martin, 2001). Universities generate new knowledge and qualify experts who, being mobile, can foster regional innovative strength (Breschi \& Lissoni, 2009). Universities are engaged in knowledge transfer partly through contract research on the regional and interregional economy (Ponds, van Oort, \& Frenken, 2010), and they are sources of technical innovations that spur the economy through patents or spin-offs (Vincett, 2010). Universities also often constitute the core of regional knowledge infrastructures by facilitating knowledge exchanges permeable enough for private business and the public sector (Owen-Smith \& Powell, 2004). Moreover, universities are often committed to their regional community: They actively participate in civil society in general through political processes of decision-making and policy formation (Glückler \& Ries, 2012; Glückler \& Suarsana, 2014; Goddard, Hazelkorn, Kempton, \& Vallance, 2016; Goddard \& Vallance, 2013; see also chapter by Goddard in this volume) and influence the regional milieu through intellectual, cultural, artistic, and moral stimulation that dynamizes social and economic life. All these dimensions of qualification, innovation, social responsibility, and empowerment are so diverse, often overlapping, and fundamentally long term in their effects on a society and its economy that they are indisputably still too complex to be expressed monetarily.

In addition to these qualitative long-term impacts, universities have quantitative short-term monetary effects. What the university and its members spend on regional goods and services increases autonomous demand and leverages production and employment within a region and beyond. Although this quantifiable periodic impact of universities is just one of their many effects, we make it the sole focus of this chapter in the context of Baden-Württemberg, a large federal state of Germany. It is one of sixteen states in the country's relatively decentralized politicoadministrative system, which grants each state considerable autonomy in matters of educational policy and budgeting. Studies on the impact attributable to organizations of higher education have a long tradition (Eisen, 1948) and have taken place on various geographical scales. In Germany, however, such studies have been conducted mostly at the geographic level of local catchment areas of university regions. In Baden-Württemberg these assessments are documented for the universities of Freiburg (Drude, 1995), Heidelberg (Glückler \& König, 2012; Gormsen, 1981; Grabitz, 1990), Constance (Fürst, 1979; Oser \& Schroeder, 1995), and Stuttgart (Becker, Heinemann-Knoch, \& Weeber, 1976), and for the Karlsruhe Institute of Technology (Kowalski \& Schaffer, 2012). With rare exceptions, such as Berlin (DIW econ, 2013) and Rhineland-Palatinate (Spehl et al., 2005), the impact assessments focus on local catchment areas rather than an entire university landscape in large economic regions.

If Baden-Württemberg were a sovereign state, it would rank as the world's 18th largest national economy, immediately before Belgium. ${ }^{1}$ It is home to 80 universities

\footnotetext{
${ }^{1}$ This calculation is our own for 2012 and is based on OECD and Macroeconomic Accounts of the Federal States (Volkswirtschafliche Gesamtrechnung der Länder, VGRdL).
} 
and 55 nonuniversity research centers, with 49 of the latter facilities being located next to one of the universities. Of these 80 universities, nine are public higher education institutions whose interests are collectively represented in the BadenWürttemberg State Rectors' Conference, which has called for an independent analysis of the economic impacts of its nine comprehensive universities. ${ }^{2}$ The significance of the state universities in Baden-Württemberg's university landscape is remarkable. Although they account for only $11 \%$ of the state's institutions of higher learning (9 out of 80), they train more than half (160,000 students in 2012) of the state's future generation of academics (Statistisches Landesamt BadenWürttemberg, 2012). These nine universities raised over $90 \%$ of BadenWürttemberg's third-party funding (or Drittmittel, hereafter called external funding) for research and teaching (Tanzmann, 2015), another sign of the disproportionate significance of the state universities.

In this chapter we first outline our research strategy for surpassing the validity and precision of conventional impact analyses of regional effects. Second, we describe our original data collection, methodology, and several key economic indicators with which to measure the monetary impact of the university landscape in BadenWürttemberg. The validity of the method rests on detailed, regionalized primary data on the expenditures of all the universities, enabling us to provide improved estimates of the regional multiplier effects by simultaneously considering rises in production and employment. Third, we present a differential incidence analysis to assess the "impact surplus" of state universities relative to alternative uses of the same public funding. Overall, we argue that the university landscape's monetary economic impact on the regional economy of Baden-Württemberg is hardly attainable by alternative uses and that its true compound social and economic benefit is still vastly underestimated.

\section{Research Strategy and Methods}

The pecuniary quantitative assessment of the economic impact of university spending is subject to three quality risks that our investigation overcomes with especially valid primary data and several methodological adjustments. The first challenge lies in correctly determining the payment flows of university spending, especially their regionalization, for the share of regional expenditures will be decisive for computing overall regional impact. This study is based on a unique database that sharply distinguishes between university spending and other expenditures at the state level.

\footnotetext{
${ }^{2}$ This chapter elaborates on an impact assessment of Baden-Württemberg's nine state universities (Glückler, Panitz, \& Wuttke, 2015) and a study of Heidelberg University's impact on its local catchment area (Glückler \& König, 2012). The analysis encompasses the universities of Freiburg, Heidelberg, Hohenheim, Constance, Mannheim, Stuttgart, Tübingen, Ulm, and the Karlsruhe Institute of Technology (including the medical schools of the universities of Freiburg, Heidelberg, Tübingen, and Ulm, but not their hospitals).
} 
The second challenge lies in assessing the multiplier effects of direct regional demand, inasmuch as additional demand for goods in the region leads to simultaneous increases in production and employment in the other upstream and downstream sectors of the economy. Theoretically, assessment of this multiplier effect requires detailed knowledge of the intersectorial division of labor in the regional economic structure and of the regional population's income-dependent consumption profiles. Little of this information is available at the regional level, however, so analysts must estimate these multipliers on the basis of assumptions. In conventional impact analyses the regional economic effect is ascertained either by means of regional supplier interdependencies (Giarratani, 1976) or through an estimate of the regional increases in income (Bathelt \& Schamp, 2002; Glückler \& König, 2012). Either approach alone underestimates overall regional impact. The procedure in this chapter combines the two multipliers, improving the quality of the results (Pischner \& Stäglin, 1976).

The third challenge lies in the erroneous assumption that the achieved regional effects would be absent if their source did not exist (Blume \& Fromm, 1999). Although this assumption seems defensible for small areas, it is not tenable in large regions (Stoetzer \& Krähmer, 2007) such as Baden-Württemberg. Particularly in large regions one must assume that funds saved in one place can (and generally will) be spent elsewhere within the limits set by the public budget. A few impact analyses pertaining to a federal state (DIW econ, 2013; Spehl et al., 2005) have ascertained only the absolute incidence. The study presented in this chapter is special in that it characterizes the differential impact of an entire university landscape in relation to alternative uses.

\section{Computation of the Direct Economic Effect}

The overall effect of the regional economic impact analysis is the sum of direct, indirect, and induced effects. The analysis starts with the gross spending of the universities and their members. This demand comprises three expenditure flows (Blume \& Fromm, 1999): (a) university expenditures for investments and for goods and services, (b) university expenditures for the wages and salaries of their employees, and (c) student living expenses. Proceeding from this gross spending, analysts must first determine its direct effect, that is, what part of it translates into demand in the region. To do so, they must calculate two things: the gross spending's impact on consumption, and that consumption's impact within the region.

First, there is the impact on demand - the direct consumption-related demand as expressed by the university's total spending on personnel, investments, and materials and by student expenditures after deduction of taxes, social security premiums, and other levies. This computation is easy for investments and spending on goods because those amounts have direct impact as payments to suppliers. It is harder to determine the impacts that wages, salaries, and student budgets have on consumption. As in previous studies, wage and salary taxes and social security premiums are 
deducted from wages and salaries ${ }^{3}$ because the taxes and premiums are not directly available for consumption. University wages and salaries are reduced by an additional amount presumed to be saved. One arrives at that sum by multiplying wages and salaries by the average savings ratio of the population in Baden-Württemberg. Because almost all students have a low income, their consumption ratio is assumed to be $100 \%$, minus administrative contributions, which are transferred in full to the state administration.

Second, regionalization determines the share of expenditures that are made within the region under study and that have a direct effect on demand. For lack of detailed data, researchers normally make numerous assumptions to estimate the regional distribution of expenditures (Friedrich \& Rahmig, 2013; Kowalski \& Schaffer, 2012). However, it is the geographic differentiation of expenditure flows that influences the overall regional effect most. Downstream specifications of the impact model depend significantly on the quality of these primary expenditure flows. In late January 2013 we joined with controlling experts of the nine state universities of Baden-Württemberg to standardize the requirements for the relevant data. Hence, all expenditures accounted for in the present study are itemized according to their type of origin and the geographic distribution of the payment flows (Table 15.1). This highly selective procedure has enabled us to track the flows of university spending in unprecedented geographical detail.

Nevertheless, analysts must still make numerous assumptions when computing effects (Table 15.2). To take account of the mobility of university personnel, we assume, as a correction based on Blume \& Fromm (1999), that 80\% of the short-term outlays by university personnel residing in Baden-Württemberg occur at their place of residence and $10 \%$ at their place of work. These figures sum to a regional quota of $90 \%$. Conversely, we assume that $10 \%$ of the short-term outlays by university personnel residing outside Baden-Württemberg occur at their place of work. Student spending within and outside Baden-Württemberg is regionalized analogously. Students residing in Baden-Württemberg thus have a regional quota of $90 \%$; those outside, 10\% (Blume \& Fromm, 1999). The direct effect of university demand is defined as the funding that is computed above as having an impact on demand and as being spent in the region.

\section{Computation of the Indirect and Induced Economic Effects}

Direct spending constitutes an autonomous rise in regional demand, which triggers a corresponding rise in production and associated supplies in related sectors of the economy. This rise in production is called the indirect effect of university demand and is ascertained during the analysis of production multipliers (Leontief, 1936). The

\footnotetext{
${ }^{3}$ In macroeconomic accounting the civil servant allowance is declared as a private household expenditure, so it is disregarded in the calculation.
} 


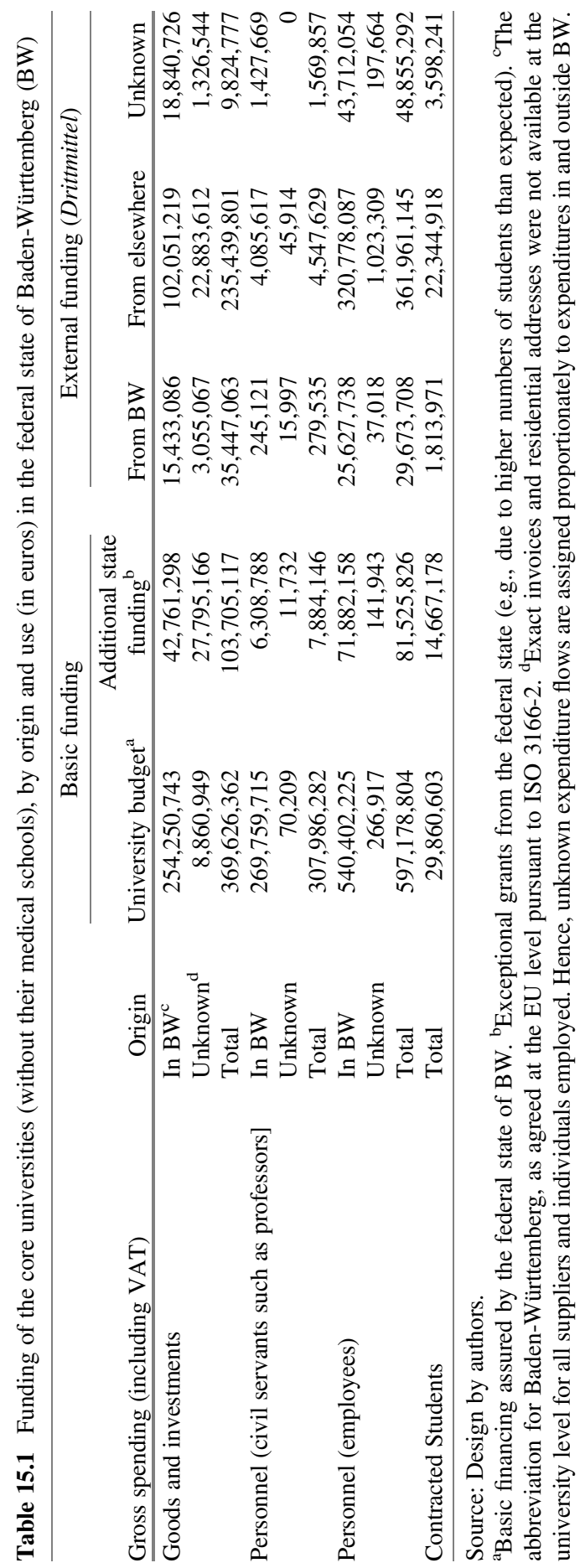


Table 15.2 Assumptions and bases of calculating the regionalization of university spending flows in Baden-Württemberg

\begin{tabular}{lcc}
\hline Variable & Assumed value & Source \\
\hline \multicolumn{2}{c}{ Employer contributions } \\
\hline Mandatory insurance & $19.58 \%$ & Inquiry at Deutsche Rentenversicherung \\
including health insurance & $7.3 \%$ & [German pension insurance authority] \\
including nursing care & $0.975 \%$ & \\
insurance & & \\
$\begin{array}{l}\text { including pension } \\
\text { insurance }\end{array}$ & $9.8 \%$ & \\
including unemployment & $1.5 \%$ & \\
insurance & &
\end{tabular}

Employee contributions

\begin{tabular}{|c|c|c|}
\hline $\begin{array}{l}\text { Mandatory insurance } \\
\text { including health insurance }\end{array}$ & $\begin{array}{l}20.48 \% \\
8.2 \%\end{array}$ & $\begin{array}{l}\text { Inquiry at Deutsche Rentenversicherung } \\
\text { [German pension insurance authority] }\end{array}$ \\
\hline $\begin{array}{l}\text { including nursing care } \\
\text { insurance }\end{array}$ & $0.975 \%$ & \\
\hline $\begin{array}{l}\text { including pension } \\
\text { insurance }\end{array}$ & $9.8 \%$ & \\
\hline $\begin{array}{l}\text { including unemployment } \\
\text { insurance }\end{array}$ & $1.5 \%$ & \\
\hline
\end{tabular}

\begin{tabular}{|c|c|c|}
\hline \multicolumn{3}{|c|}{ Regionalization of expenditures } \\
\hline Students & $\begin{array}{l}10 \% \text { at place of } \\
\text { studies }\end{array}$ & (Blume \& Fromm, 1999) \\
\hline $80 \%$ at place of residence & & \\
\hline $\begin{array}{l}\text { University personnel (includ- } \\
\text { ing civil servants such as } \\
\text { professors) } \\
80 \% \text { at place of residence }\end{array}$ & $\begin{array}{l}10 \% \text { at place of } \\
\text { work }\end{array}$ & (Blume \& Fromm, 1999) \\
\hline Employees in Baden- & $90 \%$ in Baden- & \\
\hline Württemberg & Württemberg & \\
\hline Median income tax rate & $20.7 \%$ & (Vöhringer, 2012) \\
\hline
\end{tabular}

Expenditures: goods and investments

Personnel
$12.0 \%$ (universities without medical schools)

$12.4 \%$ (with medical schools)

$15.6 \%$
Authors' computation based on information from the state universities

$$
\text { from the state universities }
$$

Inquiry at Deutsche Rentenversicherung

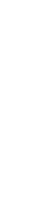


basic idea is that demand for particular goods within a region predicates prerequisite labor output inside or outside a particular region. Demand for prerequisite work generates further prerequisite work in additional upstream sectors of the economy, and so on. Eventually, this effect approaches zero asymptotically. The interdependencies of performance between the individual sectors of the economy are modeled in input-output calculations as part of macroeconomic accounting. Because inputoutput tables for Baden-Württemberg were regularly compiled by the State Statistical Office only until 1993 (Vogt, 2011), we had to compile our own input-output matrix for Baden-Württemberg. It is modeled on the national matrix of performance interdependencies and scaled to the regional, sector-specific circumstances, as in the Flegg location quotient (FLQ) procedure (Flegg, Webber, \& Elliott, 1995; Lindberg, 2010). ${ }^{4}$

This indirectly triggered rise in production also causes a rise in employment in the upstream sectors, which leads to additional income. These additional earnings by employees further increase demand for goods and operate as an induced effect on the overall regional effect of demand (Pischner \& Stäglin, 1976). The Keynesian income multiplier describes this induced rise of demand for goods by means of the underlying circulation of income, that is, by the spending of additional income, and depends decisively on the willingness of the households to consume. However, neither the production nor the income multiplier takes account of the effects of the other multiplier. We therefore use an integrative approach, bringing a Keynesian element into the regional input-output model by computing a combined multiplier (Kowalski \& Schaffer, 2012; Pischner \& Stäglin, 1976). Lastly, the direct effect of demand at production prices ${ }^{5}$ was multiplied by the foregoing combined multiplier of indirect and induced effects to determine the overall effect of regional demand at production prices. We then added in the value-added tax (VAT) for the direct and induced effects to obtain the overall effect of demand at market prices (Fig. 15.1).

\section{The Regional Economic Impact of Baden-Württemberg's State Universities}

\section{Impact on Demand}

The impact analysis starts with the gross expenditures of the universities in 2012, which amounted to $€ 3.049$ billion for investments, goods, and personnel and $€ 1.568$ billion for consumption by students. These two figures sum to a total gross demand of $€ 4.6$ billion, which constitutes the point of departure for computing the direct,

\footnotetext{
${ }^{4}$ This procedure is described in the technical appendix.

${ }^{5}$ Assumed shopping carts of university personnel and students and the expenditures of the education sector served as the basis for ascertaining each share of value-added tax, which was then deducted from demand at market prices.
} 


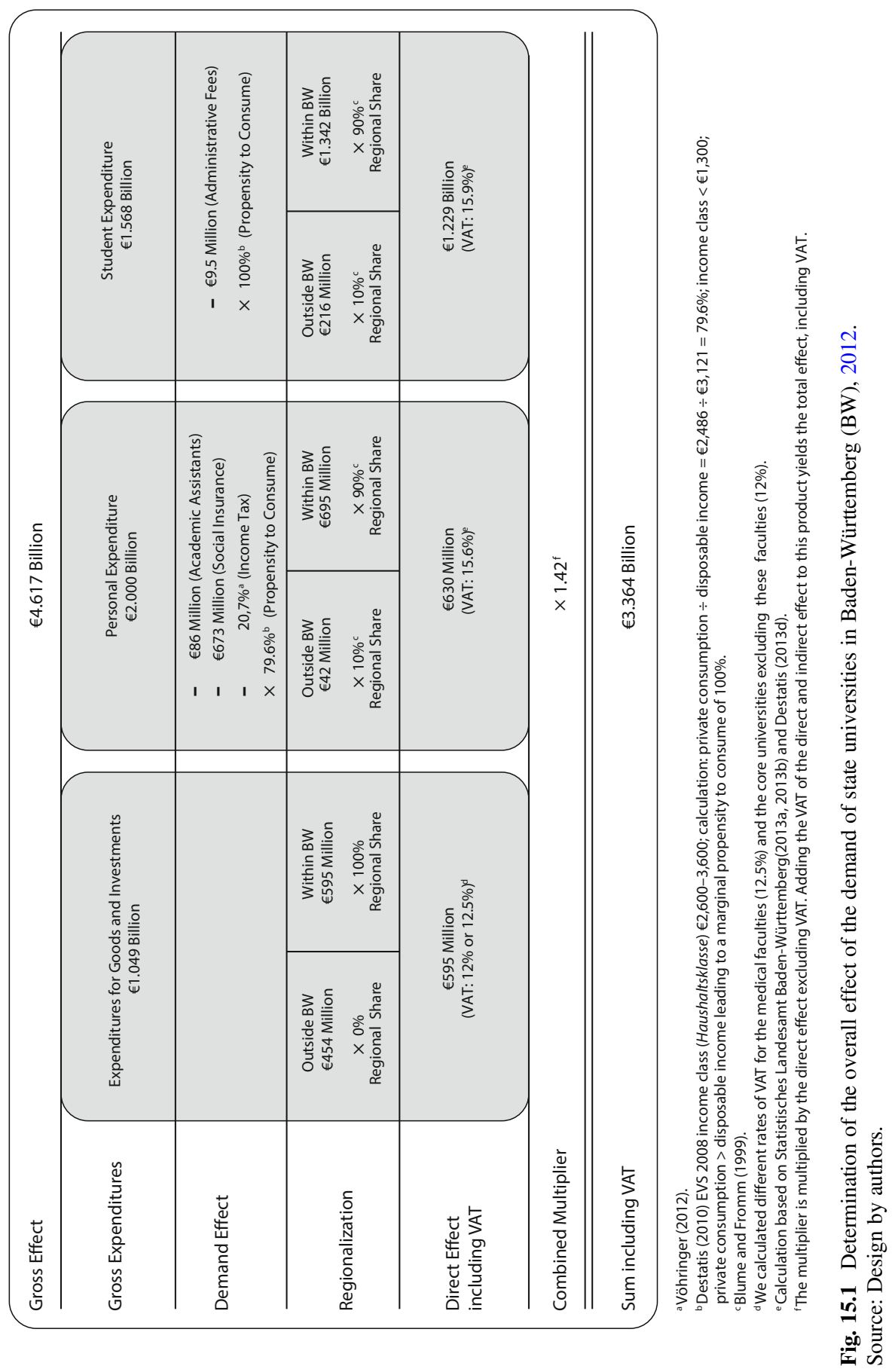


indirect, and induced effects. The state universities, except for their medical schools, spent $€ 754$ million for goods and investments, of which €470 million had an impact on demand in Baden-Württemberg (Table 15.1). Gross expenditures for personnel came to $€ 1.441$ billion, of which $€ 451$ million had an impact on demand in the region. The consumption by the 163,427 students enrolled at these universities in 2012 also increased demand for goods and services in Baden-Württemberg. With average annual receipts of $€ 799.50$ per month and student (HIS GmbH, 2010), the corresponding overall budget for students totaled $€ 1.568$ billion. After deducting the related administrative fees and taking account of the students' semester postal addresses, we found that $€ 1.229$ billion had an impact on demand directly in Baden-Württemberg. This sum corresponds to $€ 2.150$ billion as the direct effect of overall demand. In addition, the medical schools spent a total of $€ 295$ million on goods and investments in 2012, of which $€ 125$ million had an impact on demand in Baden-Württemberg. Of the $€ 559$ million in total personnel expenditures, $€ 514$ million went to persons living in Baden-Württemberg; the remaining $€ 45$ million, to persons living elsewhere. The expenditures of the medical schools accounted for $€ 304$ million of direct effect exerted by demand in Baden-Württemberg. In brief, the expenditures of the universities (including the medical faculties) came to $€ 1.049$ billion for goods and investments, $€ 2$ billion for personnel costs, and $€ 1.568$ billion in student expenditures. The resulting regional impact led to a direct effect of $€ 595$ million for goods and investment, $€ 630$ million for personnel spending, and $€ 1.229$ billion in student expenditures.

Lastly, the impact that the core universities and their medical schools had on demand in Baden-Württemberg totaled a direct effect of $€ 2.454$ billion. Because of the interdependencies of prerequisite work in the economic sectors to which this demand was directed, there were also indirect and induced effects, which were computed by means of a combined multiplier. We estimate their overall impact on demand at market prices to have been moderate, about $€ 3.364$ billion (Fig. 15.1). The overall impact of university expenditures on Baden-Württemberg's economy are also ascertainable for four other impact parameters: value creation, income, employment, and taxes (Fig. 15.2).

\section{Impact on Gross Value Added}

The impact on value added is the sum of the personnel expenditures of the state universities and the increase of gross value creation triggered by university demand in the remaining sectors. In macroeconomic accounting, gross value creation is the production value of an economic sector minus that proportion of prerequisite work which is drawn on by other economic sectors. Consequently, value creation refers only to the part of the value of goods that is added within the given sector of the economy (in the region). Because universities in Germany are governed under public law and thus not allowed to earn profits, the total personnel expenditures of $€ 2$ billion in 2012 constitute a direct impact on value creation and, hence, an expression 


Gross Effect 1 Iirect Effect

Fig. 15.2 Types and composition of economic impacts on a region.

Source: Design by authors.

of the knowledge work performed in the universities (Spehl et al., 2005). Moreover, the expenditures for goods and investments in the state universities contributed $€ 315$ million of gross value creation to the economy of Baden-Württemberg; the consumption expenditures of their personnel and the students, another $€ 886$ million. The direct effect on demand thus led to indirect gross value creation of $€ 1.201$ billion. Additional income induced by direct demand increased gross value creation by $€ 472$ million, bringing the overall effect that the state universities had on gross value creation in Baden-Württemberg to $€ 3.673$ billion in 2012 (Table 15.3). This figure amounted to approximately $1 \%$ of gross value creation in Baden-Württemberg that year.

\section{Impact on Income}

The impact on income is the sum of the university personnel's direct gross income and the additional gross income from labor that the demand of the universities gives rise to in the other sectors of the economy (Rosner \& Weimann, 2003). From the macroeconomic perspective, company profits due to effect on demand ought to be 
Table 15.3 Regional economic impacts of Baden-Württemberg's state universities, 2012 (in billions of euros)

\begin{tabular}{lccccc}
\hline Type of effect & Demand & Value-Added & Income & Employment $^{\mathrm{a}}$ & Taxes $^{\mathrm{b}}$ \\
\hline Gross & 4.617 & 2.000 & 3.127 & $40,836^{\mathrm{c}}$ & 849 \\
Regional & & & & & \\
$\quad$ Direct & 2.454 & 2.000 & 2.762 & 36,191 & $364(156)$ \\
Indirect & 630 & 1.201 & 506 & 19,558 & $399(174)$ \\
$\quad$ Induced & 280 & 472 & 52 & 7,564 & $46(20)$ \\
Overall & 3.364 & 3.673 & 3.320 & 63,313 & $809(350)$ \\
\hline
\end{tabular}

Source: Design by authors.

${ }^{\mathrm{a}}$ Refers to the number of jobs. ${ }^{\mathrm{b}}$ The parenthetic figures indicate the amount of tax revenue passed on to the state of Baden-Württemberg. ${ }^{\mathrm{c}}$ Corresponds to 32,918 full-time jobs.

included as well (Destatis, 2013b). However, it is difficult, if not impossible, to quantify these profits reliably, so the income effect is based solely on the university and regionally induced gross income from dependent labor. The overall effect comprises three factors. First, the direct incomes are the $€ 1.412$ billion of gross salaries paid by the state universities, and the incomes of their 140,667 students with semester addresses in Baden-Württemberg ( $€ 1.350$ billion). Second, the demand of the universities and their members for goods and services in Baden-Württemberg create or secure further jobs, which generate $€ 506$ million of indirect incomes. Third, these indirect incomes likewise have impacts on demand. Because of the production interdependencies between the other sectors, they generate an additional $€ 52$ billion of induced incomes. The overall effect of direct, indirect, and induced incomes came to $€ 3.320$ billion in 2012 (Table 15.3).

\section{Impact on Employment}

An alternative to representing the impact of income monetarily is to use an equivalence computation to determine the impact on the employment stemming from university demand. The total number of employees at the state universities in 2012 was 40,836 (equivalent to 32,918 full-time employees). The number of these employees residing in Baden-Württemberg was 36,191 (equivalent to 27,965 fulltime employees). The indirect impact on employment results from the increases in regional production value that are due to university expenditures and the consumption of university personnel and students. One can ascertain the number of indirectly created jobs by multiplying sectorial rise in demand with sector-specific labor coefficients. According to this calculation, the expenditures of the state universities seeded an additional 19,558 jobs in Baden-Württemberg, inducing extra demand and thereby creating an additional 7,564 jobs. Conservative computation implies that the overall effect of impact on employment was at least 63,313 jobs in BadenWürttemberg alone. This figure comes to approximately $1.2 \%$ of all persons who earn a living in Baden-Württemberg. The computation still does not include the 
many scientists, administrators, and technicians who are gainfully employed at the other universities and at research facilities outside the universities, most of whom have purposely settled near the universities. These jobs are especially valuable to Baden-Württemberg because they are relatively secure when crises hit and fairly insensitive to cyclical economic downturns.

\section{Impact on Taxes}

Baden-Württemberg receives tax revenues from university spending (VAT) and the incomes it generates (wages and income taxes). These two types of taxes account for $86 \%$ of Baden-Württemberg's tax revenues (Statistisches Landesamt BadenWürttemberg, 2013a). Altogether, total revenues of approximately $€ 809$ million within Baden-Württemberg in 2012 are attributable to the demand of the state universities and their members: approximately €401 million in VAT and €408 million in wage taxes. The other taxes are disregarded in our impact model because they are relatively unimportant. Since VAT and income taxes are federal taxes, they are shared between the federation, the states, and the municipalities through compensatory payments between the states and the federation pursuant to the vertical distribution of taxes (Bundesministerium der Finanzen, 2013). The tax revenues from Baden-Württemberg before these compensatory payments came to $€ 177$ million in VAT revenues and $€ 173$ million in wage tax revenues-a combined sum of $€ 350$ million in tax revenues from Baden-Württemberg. Adding in the $€ 9$ million of students' administrative fees that likewise accrue to the benefit of BadenWürttemberg brought Baden-Württemberg's total receipts to €359 million in 2012.

\section{Expanding the Regional Impact Model to Include Statutory Health Insurance}

Quite beyond the university expenditures, which are usually taken into account, there are further short-term effects that, in theory at least, would be measurable in monetary terms if it were not for the scarcity of precise empirical regional data. Their absence made it impossible for the regional impact model to include measurements of the indirect and induced effects of demand that reflect the company profits arising from increased production (exact operating surpluses) and the resulting additional impacts on income. Likewise, we could not take account of the returns on higher education, which have impacts on the income in a region along with subsequent impacts on the regional economy (Schubert et al., 2012).

Another unconsidered dimension in impact studies is the effect that mandatory insurance premiums have on demand for the system of statutory social insurance. Statutory social insurance in Germany consists of health insurance, nursing-care 
insurance, old-age pension insurance, and unemployment insurance. Put simply, these insurance schemes are cost-covering, pay-as-you-go systems in which the premiums received from the community of the insured are also paid out yearly as insurance benefits. With old-age, nursing-care, and unemployment insurance, however, the premiums are hardly ever paid out to the same employees who paid them in. Yet the benefits of statutory health insurance can certainly be modeled regionally because the premiums paid in the pay-as-you-go system have their impact on demand in the health-care sector during the period in which they are paid in.

We take only the university employees who have a residence in BadenWürttemberg and for whom social insurance is mandatory into account when modeling the regional economic impact of health-insurance premiums. Their insurance premiums, including the employer's contributions, amounted to $€ 189$ million in 2012. In keeping with the solidarity principle, these premiums flowed into the federal health fund and to transregional health insurers. Given the solidarity principle of equal premiums regulated by law and because wage levels differ from one region in Germany to the next, there are compensatory payments between the states. BadenWürttemberg, being a net payer, must transfer up to $5 \%$ of its collected premiums to other states (Wasem, Buchner, Lux, Manouguian, \& Schillo, 2007), so it follows that only $95 \%$ of the health-insurance premiums paid in Baden-Württemberg are actually used by insured persons in Baden-Württemberg and thus have an impact on demand in the health-care sector (Destatis, 2011a). Because part of this demand also goes to providers outside Baden-Württemberg, there is a need for a regional quota. In 2011 roughly $4.6 \%$ of all hospital patients with a residence in Baden-Württemberg were treated in hospitals beyond its borders (Destatis, 2013c). For lack of available data, our model rests on the assumption that $95 \%$ of all health-care services rendered to persons employed by the universities also have their impact in Baden-Württemberg.

We therefore had to compute a direct effect of the $€ 171$ million impact on demand in Baden-Württemberg's health-care sector. This effect is to be attributed solely to the expenditures of the state universities for statutory health insurance. This direct effect triggers a multiplier impact on indirect and induced rises in production and income in other sectors, adding up to $€ 248$ million as an overall effect of demand. This sum corresponded to a gross value creation of $€ 124$ million, an impact on employment of 1,753 jobs, and gross income of $€ 36$ million. The result was $€ 9$ million in VAT revenues and $€ 8$ million in income tax revenues, from all of which BadenWürttemberg received $€ 7$ million from the federal government.

\section{Significance of the State Universities' Impact on Baden- Württemberg's Economy}

According to the absolute-incidence analysis, the nine state universities secured more than 63,000 jobs, $€ 3.7$ billion (or $1.2 \%$ of value creation), and annual tax revenues of some $€ 350$ million in Baden-Württemberg alone in 2012. But how are 
these impacts to be assessed? The following section offers two comparative perspectives for assessing them: the overall regional economic effect of the impact on value creation in relation to the state funds used, and a differential incidence analysis comparing alternative uses of these state resources.

\section{Assessment of the Impact Relative to the Basic Funding Spent}

Baden-Württemberg provided its nine state universities with $€ 2.045$ billion of basic funding for 2012. These universities also raised additional funds and attracted the consumption expenditures of their enrolled students, achieving a total value creation of $€ 3.673$ billion. This impact is 1.8 times the basic funding of the state universities. Taking into account Baden-Württemberg's parallel tax revenues, which result from the impact that its state universities have on demand and incomes, one finds that this state's actual net use of funds declines to $€ 1.686$ billion. The overall effect of the university impact on value creation in Baden-Württemberg is thereby 2.2 times this net use of funds.

\section{Differential Incidence}

The second possibility for assessing the degree of the impact that BadenWürttemberg's nine state universities have on that state's regional economy consists of comparing alternative uses, that is, of taking the current allocation of basic funding and comparing it to allocations of those resources to other public uses. The difference between the absolute incidences of their original use and alternative uses yields the differential incidence (Stoetzer \& Krähmer, 2007) of the state universities on Baden-Württemberg's economy. So far, empirical assessments of the differential incidence are available only for impact analyses on a small scale (Assenmacher, Leßmann, \& Wehrt, 2004; DIW econ, 2008). Because numerous conceivable options exist and the analyses of specific alternatives would entail great effort, the following procedure has proven helpful. It distinguishes between three fundamental alternative uses of basic funding (DIW econ, 2008): (a) for state universities, that is, funding them from the state budget, without additional effects of external funding and student expenditures; (b) for goods and investments only; and (c) for personnel costs only, without raising additional means.

If the state universities achieve a greater absolute impact than the foregoing alternatives would, it will indicate that public funding of education and research has a surplus of short-term impact on the regional economy. This interpretation is based on the assumptions that alternative public uses of the basic funding (e.g., for administrative facilities) do not bring in any additional (external) funding and do not attract stakeholders (students) to move permanently to Baden-Württemberg. The economic impact of the state universities must therefore be compared with the multiplier effect of an alternative use by which only the state funds with regional 
impact on demand enter the regional circulation of the economy and induce additional demand through interdependencies of intersectorial prerequisite work. Scenarios for Baden-Württemberg's economy that result from an increase or decrease of state funding for the state universities can then be worked out and simultaneously weighed against the potential effects of reallocating state funding to other areas (Fig. 15.3).

In 2012 the use of one euro of state funding corresponded to a direct valuecreation impact of $€ 1.80$ in Baden-Württemberg. Cutting funds would forfeit value creation and jobs that alternative uses of public funding could not completely recoup. The quantitative difference between the impact of the state universities and that of alternative uses of the funding depends on how those resources are used. Sole reliance on basic funding of the state universities would result in a valuecreation effect of $€ 1.937$ billion (Fig. 15.3, scenario 1). Using state funding exclusively for personnel (Fig. 15.3, scenario 2) would imply greater regional impact on value creation than using it only to purchase goods (Fig. 15.3, scenario 3) but would still fall short of the impact that the state universities have. The scenario shows a net difference of at least $€ 1.173$ billion in value creation even with these reallocations of the previous funding, which did not result in any savings for the state itself.

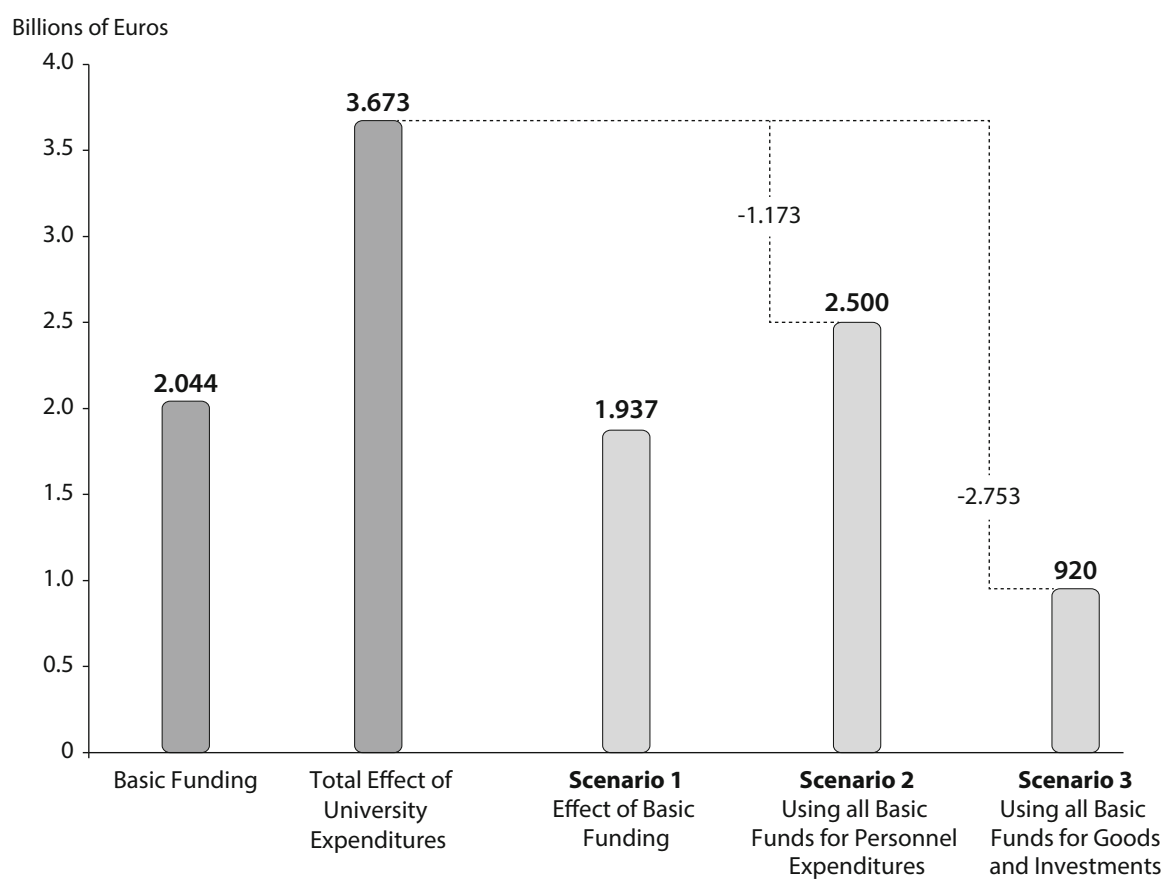

Fig. 15.3 Differential incidence of the impact that Baden-Württemberg's state universities have on gross value added.

Source: Design by authors. 


\section{Three Factors Leveraging the Relative Economic Impact Surplus of Universities}

The degree of impact that university spending has on a regional economy depends on three basic parameters: attraction of additional income due to the migration of students, acquisition of external funding, and the region's specific production and consumption profiles. The differential incidence analysis has shown that these factors are precisely what give the state universities greater leverage to strengthen regional demand than other public facilities have. Table 15.4 shows that the universities with high shares of both spending and out-of-state students are especially the ones on Baden-Württemberg's periphery. This point underlines the extraregional attractiveness of the nine state universities, which are associated with a regional flow of capital out of Baden-Württemberg as well as a flow of capital into it. Unlike the police, fire brigades, and many other public services with a clear regional jurisdiction, the universities have an impact beyond regional borders.

An exceptional case in this respect is Heidelberg University. About $55 \%$ of its students come from outside Baden-Württemberg. In the winter term 2012-2013, approximately $17 \%$ hailed from other countries; an additional $38 \%$, from other

Table 15.4 Share of expenditures, students, and external funding in Baden-Württemberg (BW)

\begin{tabular}{|c|c|c|c|}
\hline $\begin{array}{l}\text { State } \\
\text { universities }\end{array}$ & $\begin{array}{c}\text { Expenditures outside } \\
\text { BW (share of all } \\
\text { expenses), in } €\end{array}$ & $\begin{array}{l}\text { Number of students from } \\
\text { other states and countries } \\
\text { (share) }\end{array}$ & $\begin{array}{c}\text { External funding from } \\
\text { outside BW (share of all } \\
\text { funding), in } €\end{array}$ \\
\hline \multicolumn{4}{|c|}{ Universities in the center of $\mathrm{BW}$} \\
\hline $\begin{array}{l}\text { University of } \\
\text { Hohenheim }\end{array}$ & $13,235,229(11 \%)$ & $2,117(25 \%)$ & $25,240,666(20 \%)$ \\
\hline $\begin{array}{l}\text { University of } \\
\text { Tübingen }\end{array}$ & $19,993,965(9 \%)$ & $7,370(28 \%)^{*}$ & $56,120,312(23 \%)$ \\
\hline $\begin{array}{l}\text { University of } \\
\text { Stuttgart }\end{array}$ & $79,911,115(18 \%)$ & $6,910(29 \%)$ & $156,905,252(35 \%)$ \\
\hline \multicolumn{4}{|c|}{ Universities close to $\mathrm{BW}$ borders } \\
\hline $\begin{array}{l}\text { University of } \\
\text { Konstanz }\end{array}$ & $39,190,240(25 \%)$ & $3,545(32 \%)$ & $46,205,997(29 \%)$ \\
\hline $\begin{array}{l}\text { University of } \\
\text { Freiburg }\end{array}$ & $56,904,647(18 \%)$ & $8,998(43 \%)$ & $90,536,573(29 \%)$ \\
\hline $\begin{array}{l}\text { Heidelberg } \\
\text { University }\end{array}$ & $80,023,267(22 \%)$ & $15,846(55 \%)$ & $91,069,964(28 \%)$ \\
\hline $\begin{array}{l}\text { Karlsruhe } \\
\text { Institute of } \\
\text { Technology }\end{array}$ & $77,744,543(20 \%)$ & $8,546(37 \%)$ & $120,469,916(30 \%)$ \\
\hline $\begin{array}{l}\text { University of } \\
\text { Ulm }\end{array}$ & $36,714,467(29 \%)$ & $4,135(44 \%)$ & $22,808,000(17 \%)$ \\
\hline $\begin{array}{l}\text { University of } \\
\text { Mannheim }\end{array}$ & $36,206,797(36 \%)$ & $6,268(53 \%)$ & $14,936,813(14 \%)$ \\
\hline
\end{tabular}

Source: Design by authors.

*For lack of data, this figure is estimated as being similar to that for Stuttgart and Hohenheim. 
federal states within Germany. Some $22 \%$ of the university's expenses went for the consumption of goods and services and for the salaries of employees outside the region. ${ }^{6}$ Figure 15.4 , which shows the geography of spending for staff, goods, and investments in 2008, indicates the dispersed character of expenses for material goods and investments, whereas employees are concentrated largely within the universities' core region.

Overall, the attractiveness of the universities for students is an initial, important factor leveraging the impact of the regional multiplier. It was in Baden-Württemberg that $59 \%$ of all the students at the universities of Baden-Württemberg earned their university entrance qualification. Hence, $41 \%$ of all the students in Baden-Württemberg moved from other states of Germany or another country to Baden-Württemberg in order to study there. The difference between the students whose semester address was in BadenWürttemberg and those who earned their university entrance certificate in BadenWürttemberg yields a net influx of $27 \%$ of all persons enrolled at the state universities, or 44,437 students. On average in Baden-Württemberg, each student has an annual income of $€ 9,594$ (HIS GmbH, 2010), so this net influx of students alone constitutes a gross effect of $€ 426$ million of annual demand.

A second factor leveraging the great impact that the state universities have on the regional economic of Baden-Württemberg is their acquisition of external funding. Empirically, for all the states of Germany, there is a linear relationship between the level of public funding for universities and the level of external funding acquired competitively. German universities and other institutions of higher learning acquire on average an additional $€ 0.31$ of external funding for each euro received in state funding. Amounts exceeding the expected values attest to above-average acquisition of external funding, as in Berlin, Saxony, and Baden-Württemberg (Fig. 15.5). The external funding that Baden-Württemberg attracted in 2012 ( $€ 1.137$ billion) surpassed that of the two other geographically large states (North Rhine-Westphalia and Bavaria). The sum lay about $€ 109$ million, or $10 \%$, above the empirically determined expected value. Baden-Württemberg's attraction of external funding has thus been an abiding strength since 1995 (Destatis, 2013a, 2015) and is attributable mostly to the state universities. In 2012 these universities acquired an additional $€ 1.005$ billion of external funding (based on our own data collection) or roughly one half of their basic funding. In fact, Table 15.4 shows that most universities achieve a positive balance between expenditures and funding from outside Baden-Württemberg.

A third factor of the regional multiplier impact is the specific production and consumption structure of the regional context. To begin with, the portion of disposable income, which has an impact on demand as a direct effect, varies with the consumption profiles of a region's population. The higher a population's savings ratio (i.e., the percentage of savings from income not spent on consumption), the less impact income has on demand. In Baden-Württemberg the population's average

\footnotetext{
${ }^{6}$ Glückler and König (2012) offer a more detailed geographical overview of the expenses of Heidelberg University.
} 


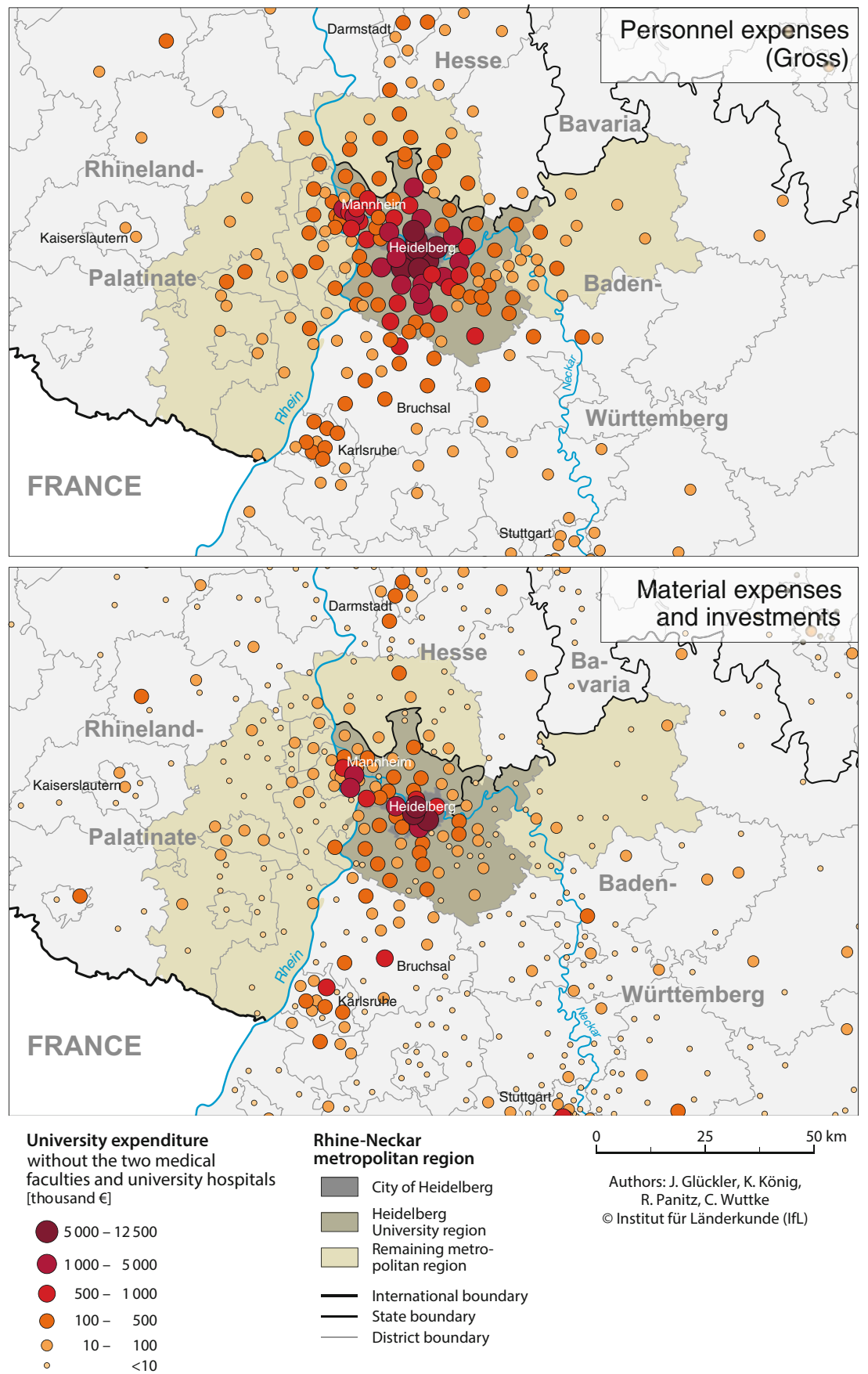

Fig. 15.4 Geographical distribution of Heidelberg University's personnel and expenditures on material (not counting the faculties of medicine), 2008.

Source: Adapted according to Glückler \& König (2012, p. 347). Copyright: Heidelberg University and IfL. Reprinted with permission. 


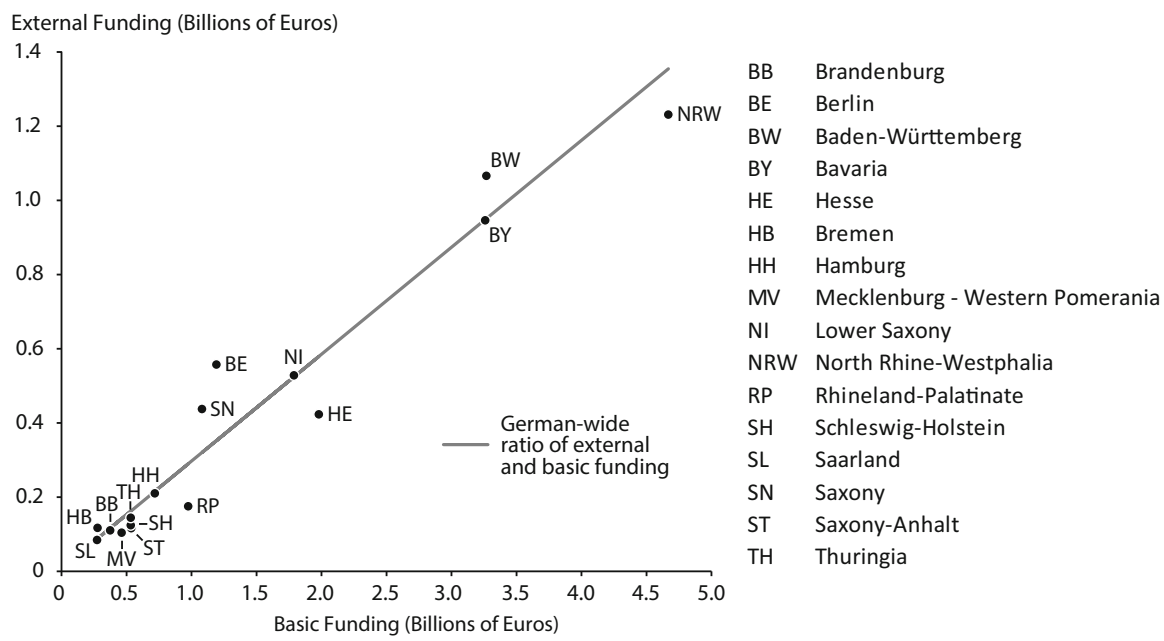

Fig. 15.5 The ratio of basic to external funding, by federal state in Germany, 2012. Source: Design by authors, data retrieved from Destatis (2015, pp. 16-18).

savings ratio $(12.6 \%)$ is above average; indeed, it is the second highest savings ratio in Germany (Destatis, 2010). With a rise in willingness to consume, direct demand could rise and thereby increase the regional impact of wages and salaries even more. Another factor influencing the regional production and consumption structure is the intersectorial division of labor in the regional production structure. The multiplier of direct effects of demand rises with the regional prerequisite work ratio. Accordingly, the greater the intraregional performance interdependencies of the sectors of the economy, the greater the multiplier impacts of an autonomous rise in demand. Empirically, the more delimited a region is, the greater the regional ratio of prerequisite work. If it is just a question of a single university's local catchment area, the import ratio is much higher than in a state the size of Baden-Württemberg, in which virtually the entire economic portfolio of goods production is represented. Because of the progressive global division of labor in many sectors of the economy, the continual rise of the export ratio, and the associated increase of trade in intermediate goods (OECD, 1999, 2010), one must assume that the regional prerequisite work ratio is rather likely to decrease in the long term. Be that as it may, universities can attract students and raise external funding but are themselves largely unable to influence these regional production and consumption profiles.

\section{Conclusion}

Universities are key actors in knowledge-driven economies. They are centers of knowledge creation and of the training of highly qualified knowledge workers who shape societies and economies in the long run. Simultaneously, universities are part of the short-term economic system of regional and national economies because they 
spend money and attract students, employees, and external funding from other regions. By assessing the short-term, periodic economic impacts that an entire university landscape has on one of the largest federal economies in Germany, we have offered an insight into the magnitude of the economic impact of universities on a large economy. Our approach has several original aspects: (a) a unique database whose information on the spatial distribution of spending has been offered with unprecedented precision by university accounting departments, (b) advanced differential impact analysis, (c) the geographical scale of a large federal state in the German economy, and (d) the inclusion of statutory health-insurance premiums.

According to our analysis, the nine state universities in Baden-Württemberg stimulate additional demand in production, value creation, and employment that almost doubles the initial basic funding that these institutions of higher education receive from the federal government. For each euro of public funding, the universities generate an impact on gross value added of at least $€ 1.8$ in Baden-Württemberg alone. At the same time, the regional demand of the universities secures more than 63,000 jobs in Baden-Württemberg and generates immediate tax revenues of $€ 350$ million ( $€ 359$ million including student fees) just for Baden-Württemberg's state administration. The aggregate impact even expands-to $€ 1.9$ per euro of basic funding - if the health-care expenditures are included. Discounting the tax revenues that Baden-Württemberg earns directly and indirectly by spending the basic funding within the same year it is received, one finds that the actual net impact of the universities is 2.3 times greater than the initial net public funding (Fig. 15.6).

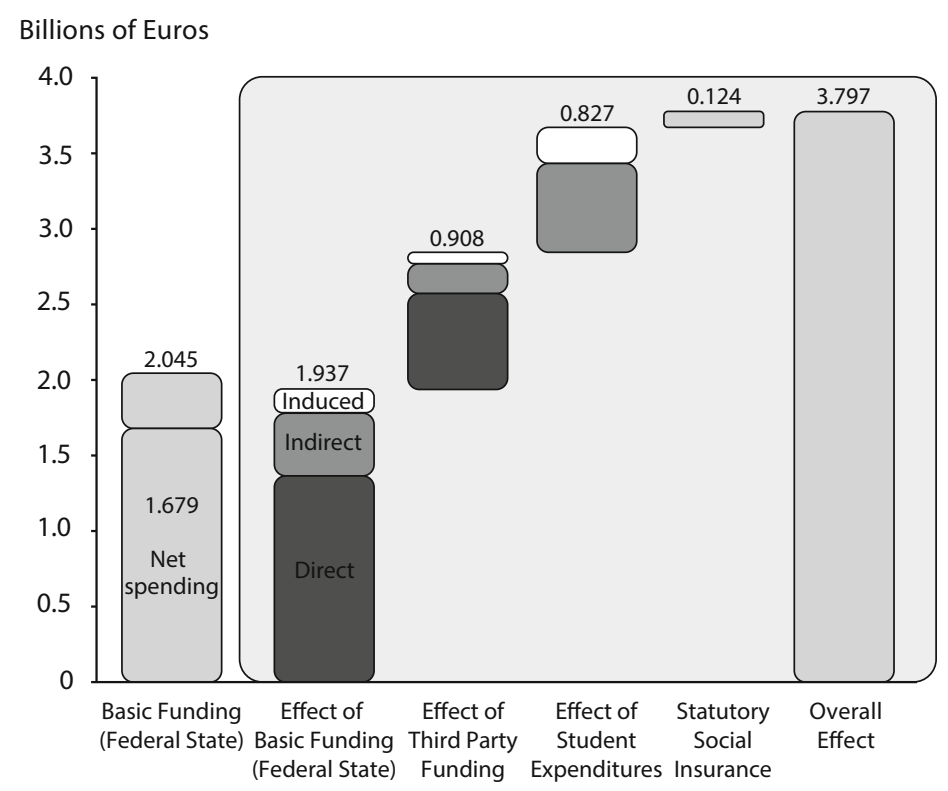

Fig. 15.6 The overall effect of value added in Germany's federal state of Baden-Württemberg, including statutory health insurance, 2012.

Source: Design by authors. 
Because the universities attract many students with purchasing power from other regions and countries and raise external funding for research and employment, it is difficult to conceive of alternative uses of public funding that would exceed these regional economic impacts.

Lastly, a disadvantage of impact analyses is that they capture only existing supplies with upstream sectors of the economy and, hence, only the static effects of the current regional economic system and its division of labor (Drucker \& Goldstein, 2007). But the decisive character of university activities lies precisely in the long-term, dynamic changes in these economic interdependencies (e.g., new technologies and sectors of the economy) and the conditions of production (e.g., increases in productivity). Experience shows that there are scarcely any important cross-sectorial technologies for which public promotion of research has not been a pivotal factor. Clearly, assessing only short-term economic impacts greatly underestimates the long-term overall economic impacts that universities have on their region and federal state.

\section{Technical Appendix}

To compute the production multiplier, we used the input coefficient matrix from a computation of Baden-Württemberg's input and output matrix. This kind of matrix is not provided by the state offices of statistics, so it must be constructed. There are two ways to construct a regional coefficients matrix: either with data based on surveys or, as in this chapter, with an estimation. The underlying model for such estimation can be based on the two matrices of national input coefficients. Because imports are assigned directly, the domestic input matrix makes for a more realistic estimate than the technological coefficients matrix does (Lindberg, 2010). The domestic input matrix was thus the point of departure for the remaining computations. To reflect regional circumstances, the matrix was scaled to a regional level through the use of local quotients. First, we scaled the national input coefficients with the help of the location quotient (LQ) (Kowalski \& Schaffer, 2012).

$$
L Q_{i}=\frac{b_{i}^{R}}{b_{i}^{N}} * \frac{b_{\sum}^{N}}{b_{\sum}^{R}}
$$

where $b_{i}^{R}$ : Number of persons employed in sector $i$ (regional).

$b_{i}^{N}$ : Number of persons employed in sector $i$ (national).

$b_{\sum}^{R}$ : Total number of persons employed (regional).

$b_{\sum}^{N}$ : Total number of persons employed (national).

Each $L Q_{i}$ shows the relative significance of regional economic sector $i$ in comparison to its national counterpart as measured by sectorial employment. If a quotient lies in the range of $L Q_{i} \geq 1$, one assumes that the sector is sufficiently specialized in the region to satisfy the demand of the other production areas and of the final 
consumers. In this case each regional input coefficient equals the corresponding national coefficient $\left(a_{i j}^{R}=a_{i j}^{N}\right)$. With a value of $L Q_{i} \leq 1$, one assumes that regional production lies below the national average. Consequently, additional prerequisite work must be imported to satisfy regional demand. The national input coefficients $\left(a_{i j}^{N}\right)$

$$
a_{i j}^{R}=a_{i j}^{N} * L Q_{i}
$$

must therefore be corrected through use of the $L Q_{i}$ in order to avoid an overestimate for the region.

This method can be refined by using the cross-industry location quotient (CILQ). The quotient compares the regional share of the persons employed in the production sector with the national value and relates it to the sector to be supplied. Thus, both the size and structure of the production sector and the sector supplied are taken into account (Kowalski \& Schaffer, 2012).

$$
C I L Q_{i j}=\frac{b_{i}^{R}}{b_{i}^{N}} * \frac{b_{j}^{N}}{b_{j}^{R}}=\frac{S L Q_{i}}{S L Q_{j}}
$$

A special case of adjusting the regional input coefficients that use the $C I L Q_{i j}$ arises with the diagonals of the matrix $(i=j)$. The value is 1 by definition. Smith and Morrison (1974) addressed this problem and proposed that the $L Q_{i}$ rather than the $C I L Q_{i j}$ be used for the cells affected.

Another problem arises because the relative sizes of the regions are not taken into account. Flegg et al. (1995) tackled this problem and developed a new procedure based on the $C I L Q_{i j}$, which they adjusted in later works by introducing the parameter $\lambda$

(Flegg \& Tohmo, 2013; Flegg \& Webber, 2000).

$$
\begin{gathered}
F L Q_{i j}=C I L Q * \lambda \\
F L Q_{i j}=\frac{b_{i}^{R}}{b_{i}^{N}} * \frac{b_{j}^{N}}{b_{j}^{R}} * \lambda \\
\text { where } \lambda=\left(\log _{2}\left(1+b_{\sum^{R}} / b_{\sum}^{N}\right)\right) .
\end{gathered}
$$

The $F L Q$, like the $C I L Q$, includes the producing and supplied sectors of the economy in the computation. However, by means of the parameter $\lambda(0 \leq \lambda<1)$, the $F L Q$ also take account of the relative size of a region (as measured by employment). The value of $\lambda$ approaches 1 with increasing region size. The exponent $\delta$ can be adjusted to influence the convexity of the function $\lambda$. This choice, however, is based on empirical work.

Recent studies on Baden-Württemberg use an exponent $\delta$ at the interval $0.11 \leq \delta$ $\leq 0.17$ because of the diversified industrial structure (Kowalewksi, 2015). In comparison to other studies, however, and in the absence of further verification, this value seems to be too low. For this study we therefore adopted the value of the empirical studies and used the $F L Q$ formula with $\delta=0.3$ (Kowalski \& Schaffer, 2012; Lindberg, 2010; Schaffer \& Siegele, 2008) when generating the regional input-output table. 
Application of $F L Q$ leads simultaneously to the procedure for deriving other localization quotients.

$$
a_{i j}^{R}=a_{i j}^{N} * F L Q_{i j}
$$

In the cases of $F L Q_{i j} \geq 1$, one has $a_{i j}^{R}=a_{i j}^{N}$.

First, the input coefficients at the federal level were scaled down according to economic sectors to the federal state level with the $F L Q$ procedure through the use of the figures for employment for which social security is mandatory (Bundesagentur für Arbeit, 2012). The resulting intersectorial interdependencies table $(A)$ for the region of Baden-Württemberg covered all 71 economic sectors pursuant to the industrial classification of 2008 and thus constituted the point of departure for the subsequent steps of the analysis.

To compute the increase of regional production caused by an increase in demand in a given sector, one must first compute the inverse prerequisite work matrix $(X)$ :

$$
X=(\mathrm{I}-\mathrm{A})^{-1}
$$

The prerequisite work matrix $(A)$ was subtracted from the identity matrix $(I){ }^{7}$ and the result was inverted. This step yielded the inverse coefficients of the intersectorial interdependencies table, also known as Leontief inverses. In the final step, we prepared an input-output table based on the regional input coefficients matrix by including the gross value creation (Destatis, 2011b) of the economic sectors in Baden-Württemberg. In adjusting gross value creation to the 71 sectors, we assumed that the relative regional productivity differences of the sectors can be derived from the relative differences at the federal level. The input-output multiplier computed in this way describes the indirect effect of rendering prerequisite work that is brought about by the direct expenditures $(\Delta Y)$ of the universities and their employees.

$$
\Delta Y=\left[\begin{array}{l}
1 \\
0 \\
0
\end{array}\right]
$$

To determine this value more precisely, the vector of additional demand $(\Delta Y)$ is multiplied by the inverse coefficients of the intersectorial interdependencies table. We can express this procedure in the following manner, using (8).

$$
X=(\mathrm{I}-\mathrm{A})^{-1} * \Delta Y
$$

\section{Computation of the income multiplier (Keynesian multiplier)}

The expansion of intersectorial production leads to an induced effect on income. The Keynesian multiplier theory describes this effect as a function of the willingness of households to consume. It states the number of units by which the income of employees grows because of marginal increases in state expenditures, consumption,

\footnotetext{
${ }^{7}$ An identity matrix is a square matrix in which the elements $a_{i i}$ of the diagonal are 1 and the other elements 0 .
} 
investments, the tax rate, and exports. This multiplier rises with each euro of additional income that the households spend. The model consists principally of two elementary equations: the balance equation and the consumption function. The balance equation defines GDP $(Y)$ in the Keynesian model as the total demand of the final consumers:

$$
Y=C+N_{0},
$$

where $Y=$ gross domestic product (GDP).

$C=$ expenditures of the private households.

$N_{O}=$ autonomous consumption (demand of the state, or some other entity).

The consumption function

$$
C=\mathrm{C}(\mathrm{Y})
$$

implies the relationship between GDP and the amount of consumption by private households. The consumption function also satisfies

$$
0<\frac{d C}{d Y}<1
$$

This equation results in the following relationship for the marginal consumption ratio $c$ :

$$
c(Y)=\frac{d C}{d Y}
$$

which also lies between 0 and 1 . When the marginal consumption ratio is constant, the GDP $(Y)$ can be expressed as

$$
Y=\mathrm{cY}+\mathrm{N}_{0} \Leftrightarrow Y=\left(\frac{1}{1-c}\right) N_{0}
$$

In this equation and under these circumstances, the GDP can be explained solely by the consumption ratio $c$ and autonomous consumption $N_{O}$.

\section{Computation of the combined multiplier}

The combined multiplier is based on the assumption that the marginal consumption ratio stays constant over the cycles and lies in the range $\omega_{2}<1$. This value causes the effect to weaken over the cycles and eventually come to a standstill. Mathematically, we can draw on equations (8) and (16) to quantify this effect on demand as follows (Kowalski \& Schaffer, 2012; Pischner \& Stäglin, 1976; Schaffer \& Siegele, 2008):

$$
\Delta Y_{1}=\omega_{1} * \omega_{2} * A^{P} *(I-A)^{-1} * \Delta Y_{0}
$$

where $\Delta Y_{1}$ : vector of additional final demand in period 1 . 
$\omega_{1}$ : marginal consumption structure of the private households. ${ }^{8}$

$\omega_{2}$ : marginal consumption ratio of the private households. ${ }^{9}$

$A^{P}$ : primary input coefficients matrix (quadrant III).

$\Delta Y_{0}$ : demand trigger in period 0 .

As already described, the additionally generated final demand $\left(\Delta Y_{1}\right)$ is the trigger for the next round. Accordingly, equation 17 can be generalized as

$$
\Delta Y_{t}=\omega_{1} * \omega_{2} * A^{P} *(I-A)^{-1} * \Delta Y_{t-1}
$$

Lastly, we can derive the combined total effect by including the final demands $\left(\Delta Y_{t}\right)$ that were generated in the rounds.

\section{References}

Assenmacher, M., Leßmann, G., \& Wehrt, K. (2004). Regionale Entwicklungsimpulse von Hochschulen: Einkommens-, Beschäftigungs- und Kapazitätseffekte der Hochschulen Anhalt und Harz $(\mathrm{FH})$ [Regional development spurred by universities: Effects of the Anhalt and Harz universities of applied sciences on income, employment, and capacity]. Harzer Hochschultexte: Vol. 7. Wernigerode: Hochschule Harz.

Bathelt, H., \& Schamp, E. W. (Eds.). (2002). Die Universität in der Region: Ökonomische Wirkungen der Johann Wolfgang Goethe-Universität in der Rhein-Main-Region [The university in the region: Economic impacts of the University of Frankfurt on the Rhein-Main region]. Frankfurter wirtschafts- und sozialgeographische Schriften: Vol. 71. Frankfurt am Main: Institut für Wirtschafts- und Sozialgeographie.

Becker, R., Heinemann-Knoch, M., \& Weeber, R. (1976). Zur Rolle einer Universität in Stadt und Region: Universität als regionaler Wirtschaftsfaktor, Mobilität von Hochschulabsolventen, Verhalten von Hochschulangehörigen im Reproduktionsbereich [On the university's role in the city and region: The university as a regional economic factor, the mobility of university graduates, and the behavior of university members in economic reproducion]. Texte und Daten zur Hochschulplanung. Berlin: De Gruyter.

Blume, L., \& Fromm, O. (1999). Regionale Ausgabeneffekte von Hochschulen: Methodische Anmerkungen am Beispiel der Universität Gesamthochschule Kassel [Regional effects of university spending: Methodological comments on the University of Kassel]. Raumforschung und Raumordnung, 57, 418-431. doi: https://doi.org/10.1007/BF03184510

Breschi, S., \& Lissoni, F. (2009). Mobility of skilled workers and co-invention networks: An anatomy of localized knowledge flows. Journal of Economic Geography, 9, 439-468. doi: https://doi.org/10.1093/jeg/lbp008

Bundesagentur für Arbeit (Federal Employment Agency). (2012). Sozialversicherungspflichtig Beschäftigte nach Wirtschaftszweigen (WZ 2008) für Baden-Württemberg [Employees for which social security is mandatory by industry sectors (WZ 2008) in the federal state of

\footnotetext{
${ }^{8}$ Destatis (2013d): Macroeconomic accounting: Personal consumption spending and available income with the following assumptions: employed persons (household type: $€ 2,600-€ 3,600$ of monthly net income) and students (household type: $<€ 1,300$ of monthly net income)

${ }^{9}$ Destatis (2010): Average German household with disposable monthly income of $€ 2,965$ and consumption expenditures of $€ 2,245$.
} 
Baden-Württemberg]. Retrieved from https://statistik.arbeitsagentur.de/Navigation/Statistik/ Statistik-nach-Themen/Statistik-nach-Themen-Nav.html

Bundesministerium der Finanzen. (2013). Der bundesstaatliche Finanzausgleich [The federal system of fiscal transfer]. Retrieved from http://www.bundesfinanzministerium.de/Content/ DE/Standardartikel/Themen/Oeffentliche_Finanzen/Foederale_Finanzbeziehungen/ Laenderfinanzausgleich/BFAG.pdf

Cooke, P., Heidenreich, M., \& Braczyk, H.-J. (2004). Regional innovation systems: The role of governance in a globalized world (2nd ed.). London: Routledge.

Destatis. (2010). Wirtschaftsrechnungen: Einkommens- und Verbrauchsstichprobe. Einnahmen und Ausgaben privater Haushalte 2008 [System of national accounts: Sample Survey of Household Income and Expenditure [EVS], 2008]. Fachserie 15, Heft 4. Retrieved from https://www.destatis.de/DE/ Publikationen/Thematisch/EinkommenKonsumLebensbedingungen/EinkommenVerbrauch/EVS_ EinnahmenAusgabenprivaterHaushalte2152604089004.pdf?_blob=publicationFile

Destatis. (2011a). Gesundheitsausgabenrechnung: Methoden und Grundlagen 2008 [National account of health spending: Methods and principles]. Retrieved from https://www.destatis.de/DE/Methoden/ Methodenpapiere/Download/Gesundheitsausgabenrechnung.pdf?_blob=publicationFile

Destatis. (2011b). VGR der Länder-Reihe 2, Kreisergebnisse Band 1 [GDP of the federal statesSeries 2, District results Vol. 1]. Retrieved from http://www.statistik-portal.de/VGRdL/tbls/ RV2014/R2B1.zip

Destatis. (2013a). Bildung und Kultur: Finanzen der Hochschulen 2011 [Education and culture: Financial accounts of higher education, 2011]. Fachserie 11, Reihe 4.5. Retrieved from https://www.destatis. de/GPStatistik/servlets/MCRFileNodeServlet/DEHeft_derivate_00010199/2110450117004.pdf

Destatis. (2013b). Glossar: Volkseinkommen [Glossary: National income]. Retrieved from https:// www.destatis.de/DE/ZahlenFakten/GesamtwirtschaftUmwelt/VGR/_Doorpage/Glossar_VGR. html

Destatis. (2013c). Krankenhauspatienten: Bundesländer, Jahre, Geschlecht, Wohnort des Patienten [Hospital patients: Federal states, years, gender, residence of patients]. Retrieved from https://www-genesis. destatis.de/genesis/online/data;jsessionid=8C2E6A75CA542F2131729D8BD3E8A113.tomcat_ GO_2_2?operation=abruftabelleBearbeiten\&levelindex $=1 \&$ levelid $=1495199774592 \&$ auswahloperation=abruftabelleAuspraegungAuswaehlen\&auswahlverzeichnis $=$ ordnungsstruktur \& auswahlziel $=$ werteabruf $\&$ selectionname $=23131-0012 \&$ auswahltext $=$ \&nummer $=2 \&$ variable $=1 \&$ name $=$ GES025\&werteabruf $=$ Werteabruf

Destatis. (2013d). Wirtschaftsrechnungen: Laufende Wirtschaftsrechnungen. Einnahmen und Ausgaben privater Haushalte 2011 [System of national accounts: Current private household income and spending, 2011]. Retrieved from https://www.destatis.de/DE/Publikationen/ Thematisch/EinkommenKonsumLebensbedingungen/EinkommenVerbrauch/ EinnahmenAusgabenprivaterHaushalte2150100117004.pdf?_blob=publicationFile

Destatis. (2015). Bildung und Kultur. Finanzen der Hochschulen 2013 [Education and culture: Financial accounts of higher education, 2013]. Fachserie 11, Reihe 4.5. Retrieved from https:// www.destatis.de/DE/Publikationen/Thematisch/BildungForschungKultur/ BildungKulturFinanzen/FinanzenHochschulen2110450137004.pdf?_blob=publicationFile

DIW econ. (2008). Wirtschaftsfaktor TU Berlin: Welchen Einfluss hat die TU Berlin auf die Berliner Wirtschaft? [The Technical University of Berlin as an economic factor: What is the impact of the Technical University of Berlin on the economy of Berlin?]. Retrieved from https:// diw-econ.de/wp-content/uploads/2014/01/20081113_Report_TU_Berlin_v1.0.pdf

DIW econ. (2013). Berliner Universitäten als Wirtschaftsfaktor: Die regionalökonomischen Effekte der Berliner Universitäten [The universities of Berlin as an economic factor: The regional economic effects of Berlin's universities]. Retrieved from https://diw-econ.de/wp-content/ uploads/2014/11/Wirtschaftsfaktor-Berliner-Universitaeten-Endbericht-v1.0.pdf

Drucker, J., \& Goldstein, H. (2007). Assessing the regional economic development impacts of universities: A review of current approaches. International Regional Science Review, 30, 20-46. doi: https://doi.org/10.1177/0160017606296731 
Drude, M. (1995). Die Albert-Ludwigs-Universität Freiburg als Wirtschaftsfaktor für die Region Freiburg/Br [The University of Freiburg as an economic factor in its region]. Freiburg: Universität Freiburg.

Eisen, E. E. (1948). Educational land use in Lake County, Ohio (University of Chicago Department of Geography Research Paper: No. 2). Chicago: Department of Geography, University of Chicago.

Etzkowitz, H. (2008). The Triple Helix: University-industry-government innovation in action. New York: Routledge.

Flegg, A. T., \& Tohmo, T. (2013). Regional input-output tables and the FLQ formula: A case study of Finland. Regional Studies, 47, 703-721. doi: https://doi.org/10.1080/00343404.2011.592138

Flegg, A. T., \& Webber, C. D. (2000). Regional size, regional specialization and the FLQ formula. Regional Studies, 34, 563-569. doi: https://doi.org/10.1080/00343400050085675

Flegg, A. T., Webber, C. D., \& Elliott, M. V. (1995). On the appropriate use of location quotients in generating regional input-output tables. Regional Studies, 29, 547-561. doi: https://doi.org/10. 1080/00343409512331349173

Friedrich, K., \& Rahmig, A. (2013). Die Universität Halle als hochrangiger regionaler Wirtschaftsfaktor: Analyse der Nachfrageeffekte der Hochschule [The University of Halle as a prominent regional economic factor: An Analysis of the demand effects of the university]. Retrieved from http://digital.bibliothek.uni-halle.de/pe/content/titleinfo/2416470

Fürst, D. (1979). Die Universität als Wirtschaftsfaktor einer Region: Die wirtschaftliche Bedeutung der Universität Konstanz für die Bodenseeregion [The university as a regional economic factor: The economic significance of the University of Konstanz in the Lake Constance region]. Konstanzer Blätter für Hochschulfragen, 16(61), 50-59.

Giarratani, F. (1976). Application of an interindustry supply model to energy issues. Environment and Planning A, 8, 447-454. doi: https://doi.org/10.1068/a080447

Glückler, J., \& König, K. (2012). The impact of Heidelberg University on the regional economy. In P. Meusburger \& T. Schuch (Eds.), Wissenschaftsatlas of Heidelberg University: Spatiotemporal relations of academic knowledge production (pp. 344-347). Knittlingen: Bibliotheca Palatina.

Glückler, J., Panitz, R., \& Wuttke, C. (2015). Die wirtschaftliche Wirkung der Universitäten im Land Baden-Württemberg [The economic impact of the state universities in the federal state of Baden-Württemberg]. Raumforschung und Raumordnung, 73, 327-342. doi: https://doi.org/ 10.1007/s13147-015-0360-9

Glückler, J., \& Ries, M. (2012). Why being there is not enough: Organized proximity in place-based philanthropy. Service Industries Journal, 32, 515-529. doi: https://doi.org/10.1080/02642069. 2011.596534

Glückler, J., \& Suarsana, L. (2014). Unternehmerisches Engagement im philanthropischen Feld: Das Beispiel Heilbronn-Franken [Corporate social responsibility in the philanthropic field: The case of Heilbronn-Franconia]. Berichte: Geographie und Landeskunde, 88, 203-221.

Goddard, J., Hazelkorn E., Kempton, L., \& Vallance, P. (2016). (Eds.). The civic university: The policy and leadership challenges. Cheltenham: Edward Elgar.

Goddard, J., \& Vallance, P. (2013). The university and the city. Regions and Cities: Vol. 63. Abingdon: Routledge.

Goldstein, H. A., Maier, G., \& Luger, M. (1995). The university as an instrument for economic and business development: U.S. and European comparisons. In D. D. Dill \& B. Sporn (Eds.), Emerging patterns of social demand and university reform: Through a glass darkly (pp. 105-133). Oxford, UK: Pergamon.

Goldstein, H. A., \& Renault, C. S. (2004). Contributions of universities to regional economic development: A quasi-experimental approach. Regional Studies, 38, 733-746. doi: https://doi. org/10.1080/0034340042000265232

Gormsen, E. (1981). Stadt und Universität in Heidelberg [City and university in Heidelberg]. In W. Fricke \& E. Gormsen (Eds.), Heidelberg und der Rhein-Neckar-Raum: Sammlung sozial- 
und stadtgeographischer Studien (pp. 111-154). Heidelberger Geographische Arbeiten: Vol. 46. Heidelberg: Selbstverlag des Geographischen Instituts der Universität Heidelberg.

Grabitz, J. (1990). Die wirtschaftliche Bedeutung der Universität Heidelberg [The economic significance of Heidelberg University]. In P. Meusburger \& J. Schmude (Eds.), Bildungsgeographische Studien über Baden-Württemberg (pp. 155-186). Heidelberger Geographische Arbeiten: Vol. 88. Heidelberg: Selbstverlag des Geographischen Instituts der Universität Heidelberg.

Hall, P. A., \& Soskice, D. W. (Eds.). (2001). Varieties of capitalism: The institutional foundations of comparative advantage. Oxford, UK: Oxford University Press.

Hamm, R., \& Wenke, M. (2002). Die Bedeutung von Fachhochschulen für die regionale Wirtschaftsentwicklung: Eine Darstellung am Beispiel der Fachhochschule Niederrhein [The role of polytechnical universities in regional economic development: The case of the University of Applied Sciences Niederrhein]. Raumforschung und Raumordnung, 60, 28-36. doi: https:// doi.org/10.1007/BF03185691

HIS GmbH. (2010). Grundauszählung zur 19. Sozialerhebung. Auszählungsreihe: Länder: BadenWürttemberg [Basic calculation for the Nineteenth Social Survey. Level: Federal States: BadenWürttemberg.]. Retrieved from http://www.sozialerhebung.de/download/19/Soz19_Ga_BadenWuerttemberg.pdf

Kowalewksi, J. (2015). Regionalization of national input-output tables: Empirical evidence on the use of the FLQ formula. Regional Studies, 49, 240-250. doi: https://doi.org/10.1080/00343404. 2013.766318

Kowalski, J, \& Schaffer, A. (Eds.). (2012). Das Karlsruher Institut für Technologie-Impulsgeber für Karlsruhe und die TechnologieRegion [The Karlsruhe Institute of Technology-Catalyst for the city of Karlsruhe and the technology region] (KIT Scientific Reports: Vol. 7630). Karlsruhe: KIT Scientific Publishing.

Leontief, W. W. (1936). Quantitative input and output relations in the economic systems of the United States. The Review of Economics and Statistics, 18, 105-125. doi: https://doi.org/10. 2307/1927837

Lindberg, G. (2010). On the appropriate use of (input-output) coefficients to generate non-survey regional input-output tables: Implications for the determination of output multipliers. Retrieved from https://www.econstor.eu/bitstream/10419/119005/1/ERSA2010_0800.pdf

Lundvall, B.-A. (Ed.). (1992). National systems of innovation: Towards a theory of innovation and interactive learning. London: Pinter.

OECD. (1999). OECD Science, Technology and Industry Scoreboard, 1999: Benchmarking knowledge-based economies. Retrieved from http://www.oecd-ilibrary.org/docserver/download/ 9299071e.pdf?expires $=1495290117 \& \mathrm{id}=\mathrm{id} \&$ accname $=$ guest $\&$ checksum=56B8FB003244002B9BB99117099F4D74

OECD. (2010). Measuring globalisation: OECD economic globalisation indicators 2010. Paris: OECD Publishing.

Oser, U., \& Schroeder, E. (1995). Die Universität Konstanz als Wirtschaftsfaktor für die Region [The University of Konstanz as an economic factor in the region]. Retrieved from http://nbnresolving.de/urn:nbn:de:bsz:352-opus-731

Owen-Smith, J., \& Powell, W. W. (2004). Knowledge networks as channels and conduits: The effects of spillovers in the Boston biotechnology community. Organization Science, 15, 5-21. doi: https://doi.org/10.1287/orsc.1030.0054

Pischner, R., \& Stäglin, R. (1976). Darstellung des um den Keynes'schen Multiplikator erweiterten offenen statischen Input-Output-Modells [Description of the open static input-output model extended by the Keyensian multiplier]. Mitteilungen aus der Arbeitsmarkt- und Berufsforschung, 9, 345-349. Retrieved from http://doku.iab.de/mittab/1976/1976_3_ MittAB_Pischner_Staeglin.pdf 
Ponds, R., van Oort, F., \& Frenken, K. (2010). Innovation, spillovers and university-industry collaboration: An extended knowledge production function approach. Journal of Economic Geography, 10, 231-255. doi: https://doi.org/10.1093/jeg/lbp036

Rosner, U., \& Weimann, J. (2003). Die ökonomischen Effekte der Hochschulausgaben des Landes Sachsen-Anhalt [The economic effects of university spending by the federal state of SaxonyAnhalt]. Retrieved from http://ids.hof.uni-halle.de/documents/t655.pdf

Salter, A. J., \& Martin, B. R. (2001). The economic benefits of publicly funded basic research: A critical review. Research Policy, 30, 509-532. doi: https://doi.org/10.1016/S0048-7333(00)00091-3

Schaffer, A., \& Siegele, J. (2008, November). Regional impacts of modern transport infrastructure-Analysis of the southern German infrastructure project Baden-Württemberg 21. Paper presented at the 55th Annual North American Meeting of the Regional Science Association International, New York.

Schubert, T., Baier, E., Hufnagl, M., Meyer, N., Schricke, E., \& Stahlecker, T. (2012). Endbericht zur Metastudie Wirtschaftsfaktor Hochschule [Final report on the meta study entitled The university as an economic factor]. Retrieved from http://www.wissenschaftsmanagementonline.de/sites/www.wissenschaftsmanagement-online.de/files/migrated_wimoarticle/ stifterverband_wirtschaftsfaktor_hochschule.pdf

Smith, P., \& Morrison, W. I. (1974). Simulating the urban economy: Experiments with input-output techniques. London: Pion.

Spehl, H., Sauerborn, K., Sauer, M., Benson, L., Feser, H.-D., v. Malottki, C., Schulze, P. M., \& Flohr, M. (2005). Regionalwirtschaftliche Wirkungen der Hochschulen und Fo rschungseinrichtungen in Rheinland-Pfalz: Wertschöpfungs-, Einkommens- und Beschäftigungseffekte durch Bau und Betrieb der Einrichtungen. Langfassung [The regional economic impact of higher education facilities in Rhineland-Palatinate: Added value, income, and employment effects of constructing and operating the facilities, extended version]. Retrieved from https://mwwk.rlp.de/fileadmin/mbwwk/Publikationen/Wissenschaft/ regionalwirtschaftliche_wirkung_HS_lang.pdf

Statistisches Landesamt Baden-Württemberg. (2012). Studierende an baden-württembergischen Hochschulen im Wintersemester 2011/12 [Students enrolled at universities in BadenWürttemberg in the 2011-2012 winter term]. Retrieved from https://www.destatis.de/ GPStatistik/servlets/MCRFileNodeServlet/BWHeft_derivate_00000797/3234_12001.pdf

Statistisches Landesamt Baden-Württemberg. (2013a). Staatliches Steueraufkommen in BadenWürttemberg seit 1952 nach Steuerarten [Tax revenues in Baden-Württemberg]. Retrieved June 25, 2013, from http://www.statistik-bw.de/FinSteuern/Steuern/LRt1808.jsp

Statistisches Landesamt Baden-Württemberg. (2013b). Umsätze und ihre Besteuerung 2011 [Revenues and taxation 2011]. Retrieved from https:/www.destatis.de/GPStatistik/servlets/ MCRFileNodeServlet/BWHeft_derivate_00003343/3941_11001.pdf;jsessionid=E3FD4B00B7 \$32\#952737F01E3D4F7866C9D3

Stoetzer, M.-W., \& Krähmer, C. (2007). Regionale Nachfrageeffekte der HochschulenMethodische Probleme und Ergebnisse empirischer Untersuchungen für die Bundesrepublik Deutschland [Regional effects of universities on demand- Methodological challenges and findings of empirical research in Germany]. Jenaer Beiträge zur Wirtschaftsforschung 06/2007. Retrieved from http://hdl.handle.net/10419/43652

Tanzmann, L. (2015). Die Finanzen der Hochschulen in Baden-Württemberg—ein Überblick [The finances of the universities in Baden-Württemberg-An overview]. Statistisches Monatsheft Baden-Württemberg, 1, 3-8. Retrieved from http://www.statistik-bw.de/Service/Veroeff/ Monatshefte/PDF/Beitrag15_01_01.pdf

Vincett, P. S. (2010). The economic impacts of academic spin-off companies, and their implications for public policy. Research Policy, 39, 736-747. doi: https://doi.org/10.1016/j.respol.2010.02.001

Vogt, V. (2011). Schätzung regionaler Exporte und Importe als Vorarbeit zu einer Input-OutputTabelle für Baden-Württemberg [Estimation of regional exports and imports as groundwork for an input-output table for Baden-Württemberg]. Statistisches Monatsheft Baden-Württemberg, 
2, 30-34. Retrieved from https://www.statistik-bw.de/Service/Veroeff/Monatshefte/PDF/ Beitrag11_02_08.pdf

Vöhringer, S. (2012). Einkommensmillionäre in Baden-Württemberg [Income millionaires in Baden-Württemberg]. Statistisches Monatsheft Baden-Württemberg, 9, 37-40. Retrieved from http://nbn-resolving.de/urn:nbn:de:0168-ssoar-405577

Wasem, J., Buchner, F., Lux, G., Manouguian, M.-S., \& Schillo, S. (2007). Die Regionaldimension in der Gesetzlichen Krankenversicherung vor dem Hintergrund des GKV-WSG [The regional dimension of statutory health insurance] (Diskussionabeitrag aus dem Fachbereich Wirtschaftswissenschaften Universität Duisburg-Essen Nr. 153). Retrieved from https://www. tdr.wiwi.uni-due.de/fileadmin/fileupload/BWL-MEDMAN/Forschung/DiskussionspapierGesu \$32\#ndheitsreformNr153.pdf

Open Access This chapter is licensed under the terms of the Creative Commons Attribution 4.0 International License (http://creativecommons.org/licenses/by/4.0/), which permits use, sharing, adaptation, distribution and reproduction in any medium or format, as long as you give appropriate credit to the original author(s) and the source, provide a link to the Creative Commons license and indicate if changes were made.

The images or other third party material in this chapter are included in the chapter's Creative Commons license, unless indicated otherwise in a credit line to the material. If material is not included in the chapter's Creative Commons license and your intended use is not permitted by statutory regulation or exceeds the permitted use, you will need to obtain permission directly from the copyright holder. 